\title{
Improving Quality Using The Kano Model in Overcoming Competition in The Service Industry
}

\author{
Meri Andriani*, Heri Irawan, Nanda Rizqa Asyura \\ Department of Industrial Engineering, Samudra University, Aceh, Indonesia \\ *Corresponding author E-mail: meri_tind@unsam.ac.id
}

\begin{abstract}
Manuscript received 15 August 2021; revised 1 Sept 2021; accepted 15 Sept 2021. Date of publication 4 Nov 2021

The tight competition in the service industry, especially hospitality, has caused hoteliers to strive to improve service quality. Improving the quality of service is carried out in various ways, one of which is increasing the occupancy rate of hotel rooms. This is different from Hotel X. Hotel X is an old hotel located in Langsa which has experienced a decrease in room occupancy from time to time. The decrease was caused by the service from hotel $\mathrm{X}$ that was still not satisfactory to customers. The purpose of this study is to identify customer dissatisfaction with the quality of hotel services and provide design proposals to improve service quality. The method used in this study is the Kano model, which is the model used to identify customer satisfaction, through questionnaires given to customers, statistical tests are used to conduct adequacy tests and data uniformity tests for questionnaire data obtained. Excel and SPSS software are used in statistical tests, Minitab 16 software is used in making coefficient diagrams of customer satisfaction levels. Results and Discussion obtained 21 attributes in the must be a category, 8 attributes in the one-dimensional category, 2 in the attractive category, and 2 in the indifferent category, the attributes which are categorized as one dimensional, attractive, and must be are attributes that are prioritized to improve service quality. In conclusion, 31 attributes are included in customer dissatisfaction with hotel X, one of which is the physical condition of the building with a dissatisfaction value of $-3,080$. There are 18 attributes as proposed designs in improving service quality, five of which are adding and completing service-related equipment, infrastructure improvement, improvement and development of standard operating procedures (SOP), periodic maintenance and replacement of service support equipment, procurement of housekeeping equipment, cleaning of facilities. and infrastructure, installation of signs, warnings, and information.
\end{abstract}

Keywords: Canoe Model, Customer Satisfaction, Hospitality Service, Service Quality.

\section{Introduction}

The business competition that is increasingly increasing makes the service and quality of goods or services produced by the company increasingly important, both for manufacturing and services. Service companies need to understand the needs and desires of consumers in terms of service so that companies can survive in business competition and can increase market share. Customer satisfaction is a major concern for the success of an organization and a prerequisite for competitiveness in today's global market. Currently, consumers are increasingly strict and accurate in choosing their services. Meeting customer needs is a must for every service industry [1]. In the service industry, the quality of service to customers is the most important factor, where customers are increasingly careful and critical in choosing service providers [2] [3]. The hospitality industry in Indonesia is experiencing rapid development. The hospitality industry has grown exponentially and is one of the most significant contributors to the advancement of the tourism industry [4] [5].

The Langsa City Government is currently developing tourist attractions to attract domestic and foreign tourists. The large growth of hotels in Langsa City due to the increase in tourists has created various choices for every hotel guest, therefore allowing guests to frequently move from one hotel to another. A hotel business can be said to be successful if there is an increase in the number of hotel room occupancy [6].

Hotel X is one of the oldest hotels in Langsa City. This hotel is located at Jalan Jenderal Ahmad Yani No. 214, Gampong Jawa, Langsa City, Langsa City, Aceh. This hotel was established in 1982 which was founded by Mr. H. Abdullah Hanafiah and Mr. Ir. H. Zakaria Sulaiman and until now still operating in serving hotel customers. This hotel is included in the medium hotel category because it has 70 rooms consisting of 52 rooms on the first floor and 18 rooms on the second floor [7]. Hotel X is facing the problem of decreasing hotel room occupancy. Some guest complaints obtained from direct observations to hotels and interviews with hotel guests such as employees who are less responsive in dealing with guest complaints, menus in hotel restaurants that do not vary, hotel room facilities such as air conditioning that does not work properly, slow wifi internet access, and so on. If the problem is not immediately addressed, the room occupancy rate can experience a continuous decline, to overcome this problem it is necessary to research planning to improve the service quality of Hotel X Kano model is one method that can improve the service quality of Hotel X which is analyzed using the Servqual dimension. Kano's customer satisfaction model was deliberately developed to classify product attributes by considering customer

Copyright $\odot$ Authors. This is an open access article distributed under the Creative Commons Attribution License, which permits unrestricted use, distribution, and reproduction in any medium, provided the original work is properly cited. 
perceptions and their effect on customer satisfaction [8]. Kano's model also classifies service quality by evaluating customer responses to the absence or presence of these attributes. The purpose of this study is to find out what service attributes have an influence on the increase and decrease in customer satisfaction so that these attributes need to be prioritized to improve the quality of their services and to know the actions that must be taken by the hotel management to improve the service quality of Hotel Kartika [9].

\section{Literature Review}

\subsection{Service quality}

Subjective measurements recognized by individuals are reflected in service quality rather than objective measurements. However, service quality is a measurement by the customer, and researchers generally perceive that not only the measurement results but also the entire service process perform sequential actions [10]. In service quality, there is a service quality dimension. This dimension represents how consumers organize information about service quality in their minds. The five dimensions of service quality are[11]:

1. Reliability: the ability to perform the promised service reliably and accurately.

2. Responsiveness: willingness to help customers and provide prompt service.

3. Assurance: Knowledge and courtesy of employees and their ability to convey trust and confidence.

4. Empathy: caring, individual attention that the company gives to its customers.

5. Tangibles: the appearance of physical facilities, equipment, personnel, and communication materials.

Quality of service is used to get customer satisfaction. Customer satisfaction shows how well the experience of using the product compares to the buyer's expected value [12]. This is the expectation that is felt by both the customer and the consumer before buying and feeling the product or service [13].

\subsection{Canoe Model}

The Kano model was developed in 1984 by Noriaki Kano. It aims to link the requirements fulfilled by a product or service with customer satisfaction and identify three types of requirements that affect final customer satisfaction, Figure 1.

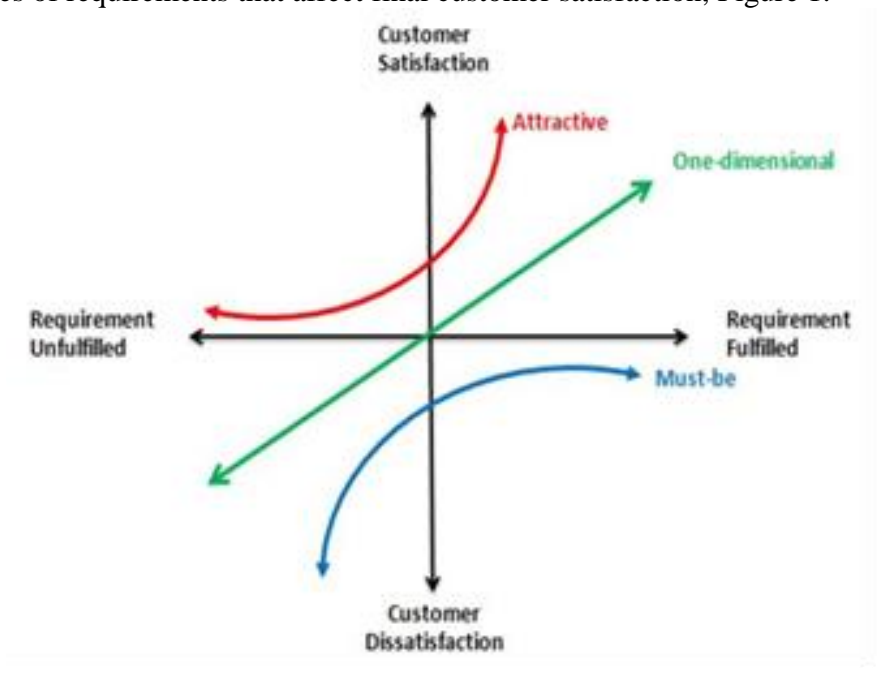

Fig 1. Canoe Model Diagram

Figure 1 presents the basic concepts of the Kano model. The horizontal axis of the diagram shows the extent to which aspects of the product meet customer requirements and the vertical axis shows the extent to which customers are satisfied with the product or service. The three main types of requirements are must-be, one-dimensional, and attractive. Must Be (expected quality) is a requirement that can lead to dissatisfaction (expected, but can not increase satisfaction). One-dimensional (desired quality) is the type where the more these requirements are met, the more satisfied clients. Attractive (Excited Quality) is a type of requirement that if it does not exist does not cause dissatisfaction, but will please the client if there is. Indifferent clients are indifferent no matter whether the feature exists or not. This reverse feature actually causes dissatisfaction [14].

The Kano methodology aims to analyze user demand and provide the most relevant requirements in the supply design stage [15]. For this purpose, the Kano questionnaire was constructed. For each quality attribute (product/service features/characteristics) there are two pairs of questions (functional and dysfunctional questions). First, we need to ask the prospect how he or she would feel if a certain feature was provided and second, the customer should answer how he or she would feel if the feature was not provided. The answers are standardized for all questions and are limited to five possibilities: "I like it". "I have to accept it", "I am neutral", "I can accept it", "I don't like it", Questioned, and vice versa. The two paired answers were analyzed based on Kano's evaluation table and the quality of each attribute (design feature) was classified into one of Kano's six available categories: must-be, one-dimensional, attractive, indifferent, questionable, and reverse. If the analyzed quality attribute falls into the must be (M) category, this emphasizes the fact that customers perceive it as an inherent basic feature and feel it is inappropriate to mention it. If designers improve such features, this will not trigger an increase in customer satisfaction but if they exclude them, customers will be very dissatisfied. When we have a one-dimensional (O) category for a particular feature, it means that the customer expects that feature to be implemented into the offering and his satisfaction will increase linearly with the enhancement/added value provided. On the other hand, attractive features (A) will surprise and delight customers if they exist but will have no negative effect if they are lost because customers do not expect quality attributes at all. The indifferent (I) category means that the customer will not be satisfied or dissatisfied with the presence or absence of the feature. The questionable (Q) category does not occur too often, meaning that the respondent is less thorough in answering or the question is not clear. If we have a large 
number of answers with questionable categories, the question requires further analysis or must be repeated [16]. The last category of reverse (R) states the inverse effect on customer satisfaction [17] [9].

Determination of the Kano category for each attribute using Blauth's Formula in the following way[18]:

1. If (one-dimensional + attractive + must-be) $>$ (indifferent + reverse + questionable) then the grade is obtained from the maximum of (one-dimensional, attractive, must-be).

2. If (one-dimensional + attractive + must-be) $<$ (indifferent + reverse + questionable) then the grade is obtained from the maximum of (indifferent + reverse + questionable).

3. If the total value (one-dimensional + attractive + must-be $)=($ indifferent + reverse + questionable) then the maximum grade is obtained among all canoe categories, namely (one-dimensional, attractive, must-be, indifferent, reverse, questionable) .

Koefisien Kepuasan Pelanggan menunjukkan sejauh mana kepuasan meningkat jika persyaratan layanan adalah terpenuhi atau sejauh mana kepuasan menurun jika persyaratan layanan tidak terpenuhi [19] [20].

\section{Methods}

This research is a continuation of previous research that used the Servqual method, therefore the questions in the Kano model questionnaire were distributed to respondents based on the Servqual dimensions. This study uses the Kano model because the method is suitable for improving the service quality.

\subsection{Samples}

The sample is determined using the accidental sampling method, which is a sample that is intentional or not. intentionally filled out a questionnaire that had been distributed [21]. Determination of the number of respondents using the rule of thumb for sample size and stating that the sample size, between 50 and 500 is appropriate[22]. The research respondents were 100 respondents.

\subsection{Questionnaire Design and Distribution}

The design of the questionnaire is to determine the service attributes that affect quality based on the Servqual dimension, where the service attributes are the needs and desires of customers or guests of Hotel Kartika. The preparation of this questionnaire is classified based on the Regulation of the Minister of Tourism and Creative Economy of the Republic of Indonesia Number PM.53/HM.001/MPEK/2013 concerning Hotel Business Standards and previous research. The questionnaire was filled out by customers or hotel guests containing the general identity of the respondents (name, age, gender, occupation, address) and several questions related to functional and dysfunctional aspects of service attributes. The scale used is Likert 1 to 5 , where "1" means dislike and "5" means like. Questionnaires were distributed to 100 hotel guests with the number of samples based on the rule of thumb. stating that the sample size, between 50 and 500 is appropriate [23][24]. The research respondents were 100 respondents.

\subsection{Procedure}

Distributing Kano Model questionnaires, then collecting data, then checking the completeness of the contents or answers to the questionnaires that have been filled out by respondents. Recapitulating the data using Microsoft Excel. The Kano Model Questionnaire was tested manually and using the SPSS program to determine whether the questionnaire data was valid and reliable, so that it could be used in data collection. Test the validity using Pearson Product Moment. The reliability test for the Kano Model questionnaire uses Cronbach's Alpha.

After the data from the Kano questionnaire was declared valid and reliable, then the service attribute classification was carried out.

\section{Result and Discussion}

The interview results obtained as many as 33 service attributes used in the research questionnaire. These attributes are used as questions in a closed questionnaire and determine the Kano category for each attribute. The identification of service attributes based on Servqual dimensions, namely tangibles, assurance, empathy, responsiveness, and reliability is as follows.

After the validity test, it shows that the questionnaire data is valid and the reliability test shows that the questionnaire data is reliable. The next step is to classify each service attribute from the Kano category by matching between the functional and dysfunctional meeting points, then determining the number of Kano categories in each service attribute for all respondents. Then by using Blauth's Formula to determine the Kano category on all service attributes. Kano's categorization on the first service attribute is the physical condition of the building, cleanliness, neatness, and good environmental comfort inside and outside the hotel with the total value $(\mathrm{O}+\mathrm{A}+\mathrm{M})$ greater than the total value $(I+R+Q)$, namely $(12+19+65)>(4+0+0)$. The grade chosen is $M$ (Must be) because $M$ (Must be) has the maximum value of $(12,19,65)$ so the first service attribute gets the Must be the category. The next service attribute also uses the same method. The recapitulation of the Kano category for each service attribute for all respondents can be seen as follows. Table 1 . shows that in the tangibles dimension, almost all service attributes are in the Kano must be a category. This means that the service attributes provided by the hotel management are a must in service, if the attributes in this category are not met, then the customer or hotel guest will not be satisfied.

Table 1. Canoe Category for Each Service Attribute for All Respondents No Number of Each Category

\begin{tabular}{|c|c|c|c|c|c|c|c|c|}
\hline & \multicolumn{6}{|c|}{ Canoe } & \multirow[t]{2}{*}{ Sum } & \multirow[t]{2}{*}{ Final Grade } \\
\hline & $\mathbf{A}$ & M & O & I & $\mathbf{Q}$ & $\mathbf{R}$ & & \\
\hline \multicolumn{9}{|c|}{ Tangibles } \\
\hline 1 & 19 & 65 & 12 & 4 & 0 & 0 & 100 & $\mathrm{M}$ \\
\hline 2 & 11 & 51 & 19 & 19 & 0 & 0 & 100 & $\mathrm{M}$ \\
\hline 3 & 15 & 53 & 17 & 15 & 0 & 0 & 100 & M \\
\hline 4 & 16 & 53 & 19 & 12 & 0 & 0 & 100 & M \\
\hline 5 & 14 & 55 & 19 & 12 & 0 & 0 & 100 & M \\
\hline 6 & 19 & 57 & 16 & 8 & 0 & 0 & 100 & M \\
\hline
\end{tabular}




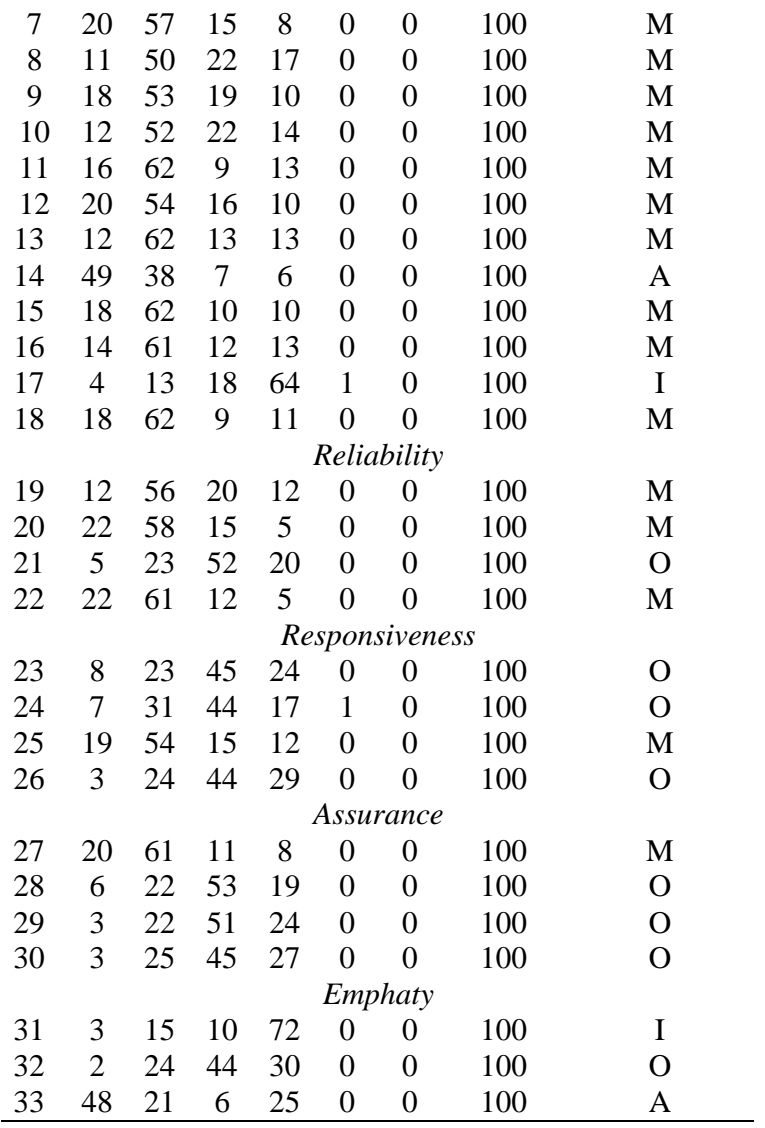

\subsection{Mapping Service Attributes into Customer Satisfaction Level Diagrams}

The input data is used to describe the location of the quadrant of each service attribute, this is done after obtaining the value of Customer Satisfaction (CS) and Customer Dissatisfaction (CD). Minitab 16 software is used in making the coefficient diagram of the level of customer satisfaction shown in Figure 2.

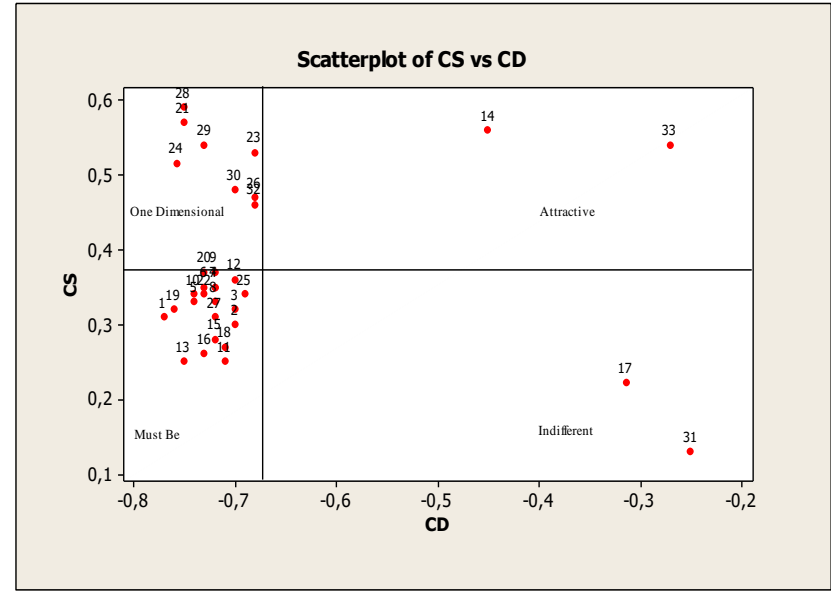

Fig 2. Customer Satisfaction Level Chart

Figure 2 shows that the must be category is the attribute most desired by customers who have a Customer Dissatisfaction value closest to -1 . The value close to -1 is the physical condition of the building, cleanliness, tidiness, and good environmental comfort inside and outside the hotel with a value of -0.770 . This shows that if the attribute that has the highest Customer Dissatisfaction value is not provided, it will have a very strong effect on customer dissatisfaction.

The service attribute most desired by customers or hotel guests in the one-dimensional category is that employees handle problems or complaints experienced by customers quickly and precisely with a value of -0.758 . This attribute has the highest Customer Dissatisfaction value. This shows that the attribute that has the highest Customer Dissatisfaction value if it is not provided then the customer is very dissatisfied.

In the attractive category, the service attribute with the highest customer dissatisfaction value is the availability of information system services with a value of -0.450 and a customer satisfaction value of 0.560 . This attribute has a fairly high customer satisfaction value, which is the third highest of all service attributes in 4 categories. This shows that if this attribute is available, the level of customer satisfaction will greatly increase. Actually, customers do not demand service attributes in the attractive category but customers will be more satisfied if the service attributes in this category can be provided by the hotel management and if these attributes are not available it will 
not reduce customer satisfaction. The high value of Customer Satisfaction on these attributes means that the performance of these attributes must be considered in order to increase because it will greatly affect the level of customer satisfaction.

In the indifferent category are attributes that do not affect the level of customer satisfaction if this attribute is available or not, therefore, it is not recommended to make improvements to service attributes that are in this category. The service attribute that has the least effect on customer satisfaction is that employees are sympathetic to customer difficulties with a Customer Dissatisfaction value of -0.250 .

It can be seen theoretically that this study supports several theories from previous research, namely the Kano model can be useful in categorizing attributes according to consumer preferences. In addition, the Kano model is a technique that can identify and prioritize features in services or products that are significant for customer satisfaction [25]. The Kano model can identify the dynamic needs of customers or hotel guests. It should be remembered that the growth of hotels in Indonesia is currently increasing rapidly so that customers will choose hotels that have the best service quality according to the needs and desires of customers, therefore, companies must have a strategy to survive in business competition, namely by providing services that can exceed customer expectations where the form of service has an attractive quality, this will create a very big difference between the quality of services provided by Hotel Kartika compared to other star hotels and make the company superior

Some practical implications of research results that can assist hotel management in improving service quality are repairing and replacing parts of buildings, building materials, components so that hotel buildings remain suitable for use and the safety of both guests and hotel employees is guaranteed, but the hotel has not been able to do this. repair or replace parts of the building in the near future because the costs to be incurred are quite large and the completion time is quite long, then add and complete equipment such as adding communication facilities in the lobby area so that hotel guests do not feel bored while waiting for room orders, then developing Standard Operating Procedures (SOPs) is done because a complete and structured SOP is a reference in doing every job, SOPs can make it easier for every employee to do work, employees can know their respective duties and responsibilities, and SOPs can also anticipate and reduce mistakes made by employees when doing their work, then maintain and replace service support equipment regularly, each employee is responsible for maintaining and caring for all facilities and equipment properly, if there is equipment that is not suitable for use it must be replaced with new ones because the equipment has an expiration date and the hotel has the cost to replace the equipment regularly, provides housekeeping equipment to maximize housekeeping employees in doing their jobs so that hotel cleanliness can be maintained well maintained, housekeeping employees are tasked with caring for and cleaning all hotel facilities and infrastructure so that they are clean, comfortable and neat, installing signs, appeals and information to make it easier for guests and employees to get the information needed, expanding the parking area due to complaints submitted by one of the hotel guests is a parking area that is not spacious enough for that the hotel should be able to expand the parking area but this proposed improvement is difficult to do because there is no land for expanding the parking area, recruiting experienced security, because the 28th attribute is that employees are able to convince customers to hotel security have the highest level of customer satisfaction, therefore, security is needed who is experienced in maintaining hotel security, but this proposed improvement is difficult to do because the number of security is sufficient and the security recruitment process takes time. For a long time, chef qualifications function to provide good quality menus and food tastes for hotel guests, improve the food and beverages management system to produce ways of providing services ranging from serving food and drinks, maintaining cleanliness, hygiene and neatness of the work environment, equipment and employees, arranging colors, selecting and arranging furniture, lighting, building and garden concepts so that the hotel looks more attractive so that customers are interested in staying at the hotel, but this is difficult for the hotel management to do because the costs incurred are quite large and require sufficient time. increasing the use of modern equipment and technology such as the use of a master key or electronic security key card so that it becomes safer when guests are in the room and when guests leave their belongings in the hotel room while traveling, conduct training for employees regularly periodically to increase employee knowledge of their work duties and responsibilities, improve skills and employees have better morals and commitment in the future, if employees have worked well then the hotel should reward employees with the best performance, this can motivate employees to work even better. The hotel management should conduct a customer satisfaction survey by asking hotel guests about how they feel about the services provided by the hotel, whether or not guests are satisfied with the services at the hotel, and guests can also provide criticism and suggestions for consideration. for the hotel management in improving the quality of its services.

\section{Conclusion}

In analyzing service quality, in Kano's model, there are 4 groups of categories, namely must-be, attractive, indifferent, and onedimensional. In the must-be category, 21 attributes must be fulfilled, if they cannot be fulfilled, it causes a decrease in the level of customer satisfaction. The must-be category attribute should be owned by the hotel. In the one-dimensional category, there are 8 service attributes. In this category, if the hotel can meet this attribute, the level of customer satisfaction will increase increases, but if the hotel cannot meet the attributes in this category, the level of customer satisfaction decreases. In the attractive category, there are 2 attributes which if the attributes in this category can be met it will increase customer satisfaction but if it cannot be fulfilled it will not reduce the level of customer satisfaction. In the indifferent category, there are 2 service attributes. In this category, whether or not the attributes are met, these attributes do not affect whether or not customers are satisfied with the quality of these attributes. After obtaining priority attributes that must be improved the quality of service based on the Kano category, corrective action is needed to improve and improve the quality of hotel services by customer needs and desires to meet customer expectations and create customer satisfaction.

\section{References}

[1] H. T. Nguyen, "An application of the Kano model and retail service quality scale to Vietnamese supermarkets," Int. J. Product. Qual. Manag., vol. 31, no. 2, pp. 189-206, 2020, doi: 10.1504/IJPQM.2020.110025.

[2] M. Andriani and H. Irawan, "Perancangan Sistem Informasi Pemesanan Kamar Hotel Berbasis Website (Web) Menggunakan Data Flow Diagram (Dfd)," Jisi J. Integr. Sist. Ind., vol. 7, no. 2, pp. 111-122, 2020.

[3] D. Riyan Rizaldi, A. Doyan, Z. Fatimah, M. Zaenudin, and M. Zaini, "Strategies to Improve Teacher Ability in Using The Madrasah E-Learning Application During the COVID-19 Pandemic,” Int. J. Eng. Sci. Inf. Technol., vol. 1, no. 2, 2021, doi: 10.52088/ijesty.v1i2.47.

[4] N. Y. Goryushkina, D. V. Shkurkin, A. S. Petrenko, S. Y. Demin, and N. S. Yarovaya, "Marketing management in the sphere of hotel and tourist services," Int. Rev. Manag. Mark., vol. 6, no. 6, pp. 207-213, 2016.

[5] L. P. Tuti Ariani, "The Effect Of Repetition Sprint Training Method Combined With The Level Of Physical Fitness Toward The Speed Of 100 Meter Run," Int. J. Eng. Sci. Inf. Technol., vol. 1, no. 3, 2021, doi: 10.52088/ijesty.v1i3.89. 
[6] S. Ali Rafsanjani, F. E. Rooslan Santosa, and R. Durrotun Nasihien, "Analysis of Planning for Clean Water Needs at Grand Sagara West Surabaya Hotel With the Green Buillding Concept," Int. J. Eng. Sci. Inf. Technol., vol. 1, no. 2, 2021, doi: 10.52088/ijesty.v1i2.55.

[7] J. S Pasaribu, "Development of a Web Based Inventory Information System," Int. J. Eng. Sci. Inf. Technol., vol. 1, no. 2, 2021, doi: 10.52088/ijesty.v1i2.51.

[8] B. L. Cheng, C. C. Gan, B. C. Imrie, and S. Mansori, "Service recovery, customer satisfaction and customer loyalty: evidence from Malaysia's hotel industry,” Int. J. Qual. Serv. Sci., vol. 11, no. 2, pp. 187-203, 2019, doi: 10.1108/IJQSS-09-2017-0081.

[9] R. Rinaldy and M. Ikhsan, "Determinant Analysis Of Conflict On Project Results In Aceh Province," Int. J. Eng. Sci. Inf. Technol., vol. 1, no. 1, 2021, doi: 10.52088/ijesty.v1i1.37.

[10] A. M. Gregory, H. G. Parsa, K. Nusair, D. J. Kwun, and S. Putrevu, "Examining the effects of vacation ownership product attributes on customer satisfaction: An investigation of product purchase and use," Int. J. Contemp. Hosp. Manag., vol. 27, no. 1, pp. 52-70, 2015, doi: 10.1108/IJCHM-07-2013-0284.

[11] S.-H. Park, H.-J. Gwon, and Y.-Y. You, "A Study on the Consulting Service Quality using Kano Model," Indian J. Sci. Technol., vol. 9, no. 43, 2016, doi: 10.17485/ijst/2016/v9i43/105020.

[12] J. L. Jones and M. Shandiz, "Service Quality Expectations: Exploring the Importance of SERVQUAL Dimensions from Different Nonprofit Constituent Groups," J. Nonprofit Public Sect. Mark., vol. 27, no. 1, pp. 48-69, 2015, doi: $10.1080 / 10495142.2014 .925762$.

[13] A. A. Razak and M. F. Shamsudin, "The influence of atmospheric experience on Theme Park Tourist's satisfaction and loyalty in Malaysia," Int. J. Innov. Creat. Chang., vol. 6, no. 9, pp. 10-20, 2019.

[14] M. F. Shamsudin, N. Nurana, A. Aesya, and M. A. Nabi, "Role of university reputation towards student choice to private universities," Opcion, vol. 34, no. Special Issue 16, pp. 285-294, 2018.

[15] R. G. Harijith and H. Naduthodi, "Kano Model Customer Satisfaction Analysis of Medical Services," Int. Res. J. Eng. Technol., vol. 4, no. 6, pp. 1426-1429, 2017.

[16] Y. Liao, C. Yang, and W. Li, "Extension innovation design of product family based on kano requirement model," Procedia Comput. Sci., vol. 55, no. Itqm, pp. 268-277, 2015, doi: 10.1016/j.procs.2015.07.045.

[17] A. Branea, S. A. Potra, A. P. Pugna, and M. Gaman, "Assessing Relevant Quality Attributes For Designing an Ergonomic Dorm Room Within The Romanian Context," vol. 64, pp. 135-144, 2021.

[18] S. A. Potra, M. Izvercian, A. P. Pugna, and J. J. Dahlgaard, "The HWWP, a refined IVA-Kano model for designing new delightful products or services," Total Qual. Manag. Bus. Excell., vol. 28, no. 1-2, pp. 104-117, 2017, doi: 10.1080/14783363.2015.1050168.

[19] N. Hidayat et al., "Analisis Peningkatan Kualitas Pelayanan Di Perpustakaan Universitas Negeri Padang (Unp) Dengan," J. Multidiscip. Res. Dev., vol. 1, no. 1, pp. 28-39, 2018.

[20] C. S. Silvia, M. Ikhsan, M. Safriani, and T. P. Gusmilia, "Efficiency Rainwater Harvesting at the Roof Campus Buildings," Int. J. Eng. Sci. Inf. Technol., vol. 1, no. 3, 2021, doi: 10.52088/ijesty.v1i3.80.

[21] S. Mote, V. Kulkarni, and D. B. E. Narkhede, "Kano Model application in new service development and Customer satisfaction," IOSR J. Bus. Manag., vol. 18, no. 08, pp. 10-14, 2016, doi: 10.9790/487x-1808011014.

[22] G. A. Khaskheli, "A mediation analysis of social media marketing between the relationship of entrepreneurial marketing strategies and the performance of small \& medium enterprises in Pakistan," Indian J. Sci. Technol., vol. 13, no. 29, pp. 2024-2034, 2020, doi: $10.17485 / \mathrm{ijst} / \mathrm{v} 13 \mathrm{i} 29.1035$.

[23] E. I. Obilor and E. C. Amadi, “Test for significance of Pearson's correlation coefficient (r)," Int. J. Innov. Math. Stat. Energy Policies, vol. 6, no. 1, pp. 11-23, 2018.

[24] L. J. Cronbach, "Coefficient alpha and the internal structure of tests," Psychometrika, vol. 16, no. 3, pp. 297-334, 1951, doi: 10.1007/BF02310555.

[25] M. Jesica, G. Testiana, and S. Rahayu, “Analisis Pengembangan Website Menggunakan Metode Kano (Studi Kasus : BRSPDF Budi Perkasa Palembang),” vol. 10, no. 02, 2019. 